This report was prepared as an account of work sponsored by an agency of the United States Government. Neither the United States Government nor any agency thereof, nor any of their employees, makes any warranty, express or implied, or assumes any legal liability or responsibility for the accuracy, completeness, or usefulness of any information, apparatus, product, or process disclosed, or represents that its use would not infringe privately owned rights. Reference herein to any specific commercial product, process, or service by trade name, trademark, manufacturer, or otherwise does not necessarily constitute or imply its endorsement, recommendation, or favoring by the United States Government or any agency thereof. The views and opinions of authors expressed herein do not necessarily state or reflect those of the United States Government or any agency thereof.

\title{
Cost Effectiveness of the 1993 Model Energy Code in Colorado
}

R. G. Lucas

June 1995

Prepared for

the U.S. Department of Energy

under Contract DE-AC06-76RLO 1830

Pacific Northwest Laboratory

Richland, Washington 99352 



\section{DISCLAIMER}

Portions of this document may be illegible in electronic image products. Images are produced from the best available original document. 


\section{Summary}

This report documents an analysis of the cost effectiveness of the Council of American Building Officials' 1993 Model Energy Code (MEC) building thermal-envelope requirements for single-family homes in Colorado. The goal of this analysis was to compare the cost effectiveness of the 1993 MEC to current construction practice in Colorado based on an objective methodology that determined the total life-cycle cost associated with complying with the $1993 \mathrm{MEC}$. This analysis was performed for the range of Colorado climates.

The costs and benefits of complying with the 1993 MEC were estimated from the consumer's perspective. The time when the homeowner realizes net cash savings (net positive cash flow) for homes built in accordance with the 1993 MEC was estimated to vary from 0.9 year in Steamboat Springs to 2.4 years in Denver. Compliance with the $1993 \mathrm{MEC}$ was estimated to increase first costs by $\$ 1190$ to $\$ 2274$, resulting in an incremental down payment increase of $\$ 119$ to $\$ 227$ (at $10 \%$ down). The net present value of all costs and benefits to the home buyer, accounting for the mortgage and taxes, varied from a savings of $\$ 1772$ in Springfield to a savings of $\$ 6614$ in Steamboat Springs. The ratio of benefits to costs ranged from 2.3 in Denver to 3.8 in Steamboat Springs. 


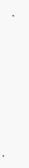

. 


\section{Contents}

Summary $\ldots \ldots \ldots \ldots \ldots \ldots \ldots \ldots \ldots \ldots \ldots \ldots \ldots \ldots \ldots \ldots \ldots \ldots \ldots$

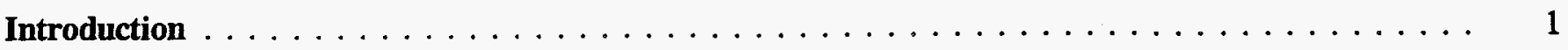

Cost Effectiveness of the 1993 Model Energy Code $\ldots \ldots \ldots \ldots \ldots \ldots$

Costs and Benefits of the 1993 Model Energy Code $\ldots \ldots \ldots \ldots \ldots$

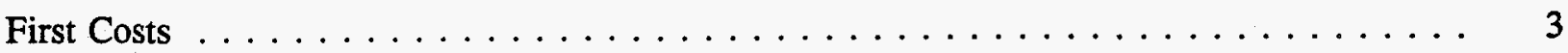

Mortgages: Down Payment, Monthly Payment, and Tax Deductions $\ldots \ldots \ldots \ldots$

Energy Cost Savings $\ldots \ldots \ldots \ldots \ldots \ldots \ldots \ldots \ldots \ldots \ldots \ldots \ldots$

Time to Positive Cash Flow $\ldots \ldots \ldots \ldots \ldots \ldots \ldots \ldots \ldots \ldots \ldots$

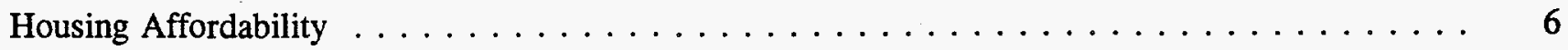

Life-Cycle Costing $\ldots \ldots \ldots \ldots \ldots \ldots \ldots \ldots \ldots \ldots \ldots \ldots \ldots \ldots \ldots \ldots \ldots \ldots$

Methodology . . . . . . . . . . . . . . . . . . . . . . . . . 11

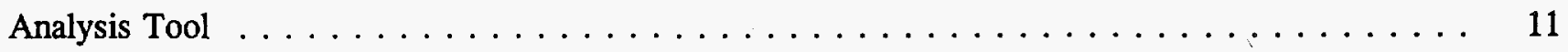

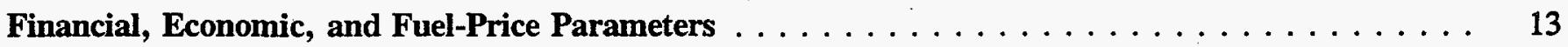

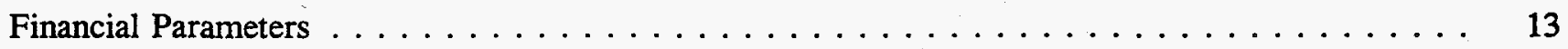

Alternate Investment Rate (Discount Rate) $\ldots \ldots \ldots \ldots \ldots \ldots \ldots \ldots$

Inflation Rate $\ldots \ldots \ldots \ldots \ldots \ldots \ldots \ldots \ldots \ldots \ldots \ldots \ldots \ldots \ldots \ldots \ldots \ldots$

Period of Analysis and Building Lifetime $\ldots \ldots \ldots \ldots \ldots \ldots \ldots$

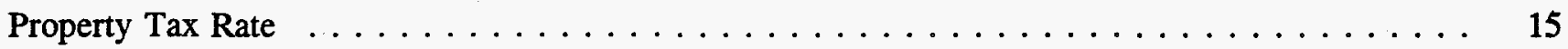

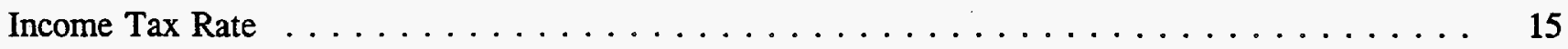

Fuel-Price Parameters $\ldots \ldots \ldots \ldots \ldots \ldots \ldots \ldots \ldots \ldots \ldots \ldots$

Fuel-Price Data $\ldots \ldots \ldots \ldots \ldots \ldots \ldots \ldots \ldots \ldots \ldots$

Fuel-Price-Escalation Rates $\ldots \ldots \ldots \ldots \ldots \ldots \ldots \ldots \ldots \ldots$

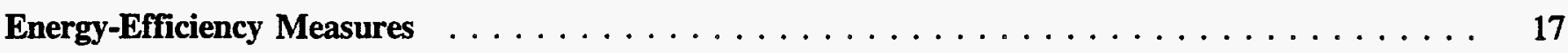

Thermal-Envelope Energy-Efficiency Measures $\ldots \ldots \ldots \ldots \ldots \ldots \ldots$ 
Energy-Efficiency Measure Costs $\ldots \ldots \ldots \ldots \ldots \ldots \ldots \ldots \ldots$

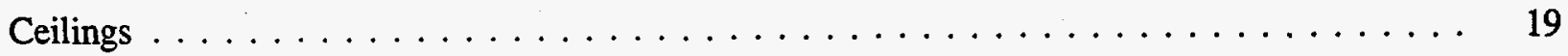

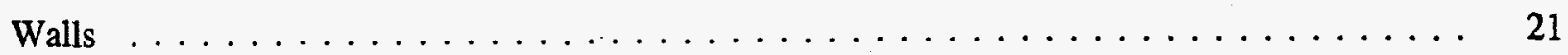

Windows $\ldots \ldots \ldots \ldots \ldots \ldots \ldots \ldots \ldots \ldots \ldots \ldots \ldots \ldots \ldots \ldots \ldots \ldots \ldots$

Doors $\ldots \ldots \ldots \ldots \ldots \ldots \ldots \ldots \ldots \ldots \ldots \ldots \ldots \ldots \ldots \ldots \ldots$

Basement Walls . . . . . . . . . . . . . . . . . . . . 25

Prototype Single-Family Home . . . . . . . . . . . . . . . . . . . 25

Heating, Ventilating, and Air-Conditioning Specifications . . . . . . . . . . . 26

Distribution Systems Efficiency $\ldots \ldots \ldots \ldots \ldots \ldots \ldots \ldots \ldots \ldots \ldots \ldots$

References $\ldots \ldots \ldots \ldots \ldots \ldots \ldots \ldots \ldots \ldots \ldots \ldots \ldots \ldots \ldots \ldots \ldots$

Appendix - Selection of Alternate Investment Rate $\ldots \ldots \ldots \ldots \ldots \ldots \ldots$ 


\section{Figures}

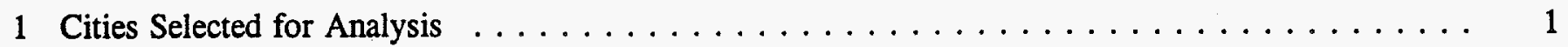

2 First Cost Impacts $\ldots \ldots \ldots \ldots \ldots \ldots \ldots \ldots \ldots \ldots \ldots \ldots \ldots \ldots \ldots \ldots \ldots$

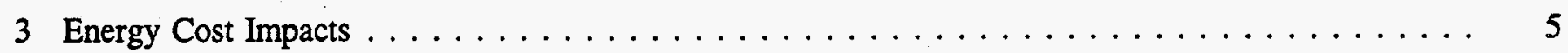

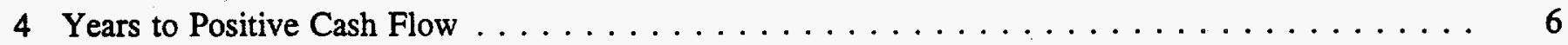

5 Typical Cash Flow for the First Owner of a Single-Family Home . . . . . . . . . . . . 7

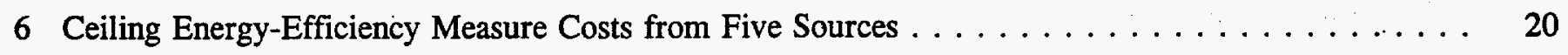

7 Wall Energy-Efficiency Measure Costs from Two Sources . . . . . . . . . . . . . . 22

\section{Tables}

1 Impacts of Mortgage Costs $\ldots \ldots \ldots \ldots \ldots \ldots \ldots \ldots \ldots \ldots \ldots \ldots \ldots$

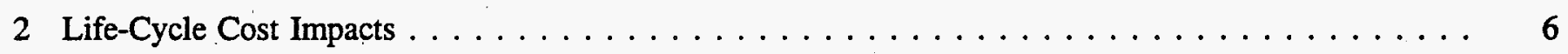

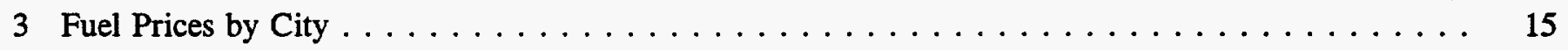

4 Residential Fuel-Price-Escalation Rates, 1995 through 2024 . . . . . . . . . . . . . . . . . 16

5 Energy-Efficiency Measures for Current Practice and 1993 Model Energy Code $\ldots \ldots \ldots$. . . . . 17

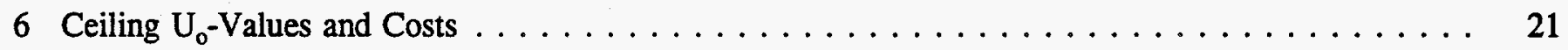

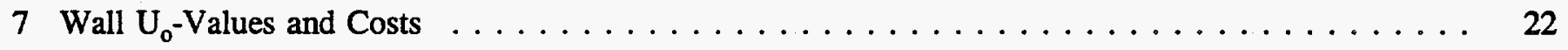

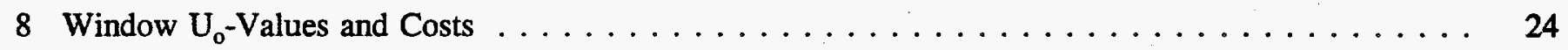

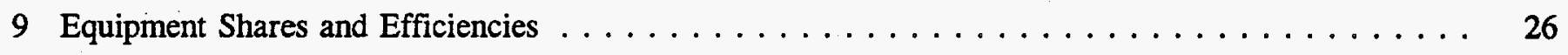




\section{Introduction}

This report documents the analysis of the cost effectiveness, in the state of Colorado, of the Council of American Building Officials' 1993 Model Energy Code (MEC) (CABO 1993) building thermal-envelope requirements. This analysis was conducted by Pacific Northwest Laboratory ${ }^{(a)}$ and was funded by the U.S. Department of Energy for the Colorado Governor's Office of Energy Conservation.

This study examined the costs and benefits associated with installing energyefficiency measures (EEMs) needed to comply with the requirements of the 1993 MEC. The EEMs include window types (e.g., double-pane vinyl) and insulation levels (e.g., R-19) for ceilings, above-grade walls, and basement walls. The analysis identifies the change in construction, financing, and energy costs to the owners resulting from making the energy-efficiency construction changes needed to comply with the 1993 MEC.

Six Colorado cities were selected for this analysis, as shown in Figure 1. These six cities were selected to highlight the range of climates in Colorado and the corresponding changes in 1993 MEC requirements with climate. The $1993 \mathrm{MEC}$ thermal-envelope requirements are a function of heating degree-days, a measure of heating-season severity. The cities are presented

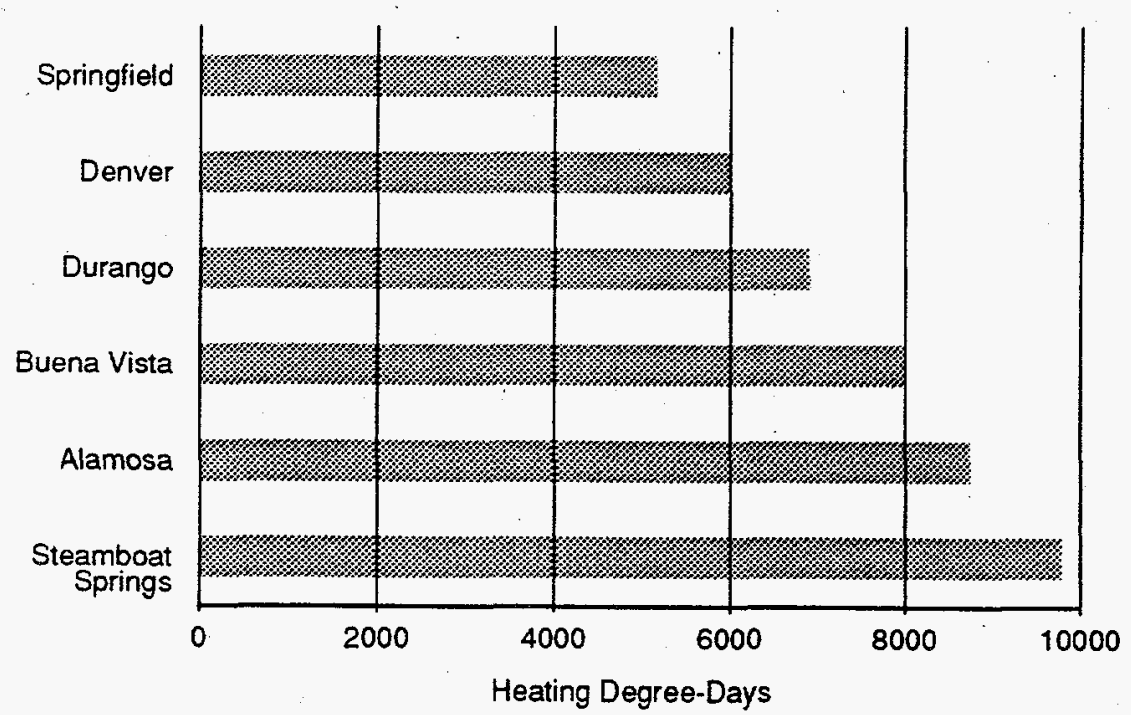

Figure 1. Cities Selected for Analysis

(a) Pacific Northwest Laboratory is a multiprogram laboratory operated for the U.S. Department of Energy under Contract DE-AC06-76RLO 1830 by Battelle Memorial Institute. 
here and in the remainder of the report in order of mildest (Springfield) to coldest (Steamboat Springs) location. Figure 1 shows the heating degreedays for each of the six cities.

As a rule, the goal was to select the most accurate and appropriate sources and data as input parameters into the analysis. Some of the data was provided by staff at the Colorado Office of Energy Conservation. In other cases, recent, well-respected, and well-documented sources were used. When good parameter value data were lacking, best judgment was used in this analysis.

This report is organized as follows. The results of the costs and benefits measures, including the estimated impacts of the 1993 MEC on homeowners in Colorado, are given in the next section. A discussion of the choice of the financial, economic, and fuel-price parameters used in the lifecycle cost analysis follows. The EEMs typically used in current practice and the EEMs needed for compliance with the 1993 MEC, their characteristics, and costs are given. The references cited in the text are presented, and an appendix on the selection of an alternate investment rate is included. 


\section{Cost Effectiveness of the 1993 Model Energy Code}

Costs and Benefits of the 1993 Model Energy Code

\section{First Costs}

Mortgages: Down Payment, Monthly Payment, and Tax Deductions
This section presents the findings of the cost/benefit analysis of increasing insulation levels and improving windows in Colorado homes to the levels necessary to comply with the 1993 MEC. All results reflect the changes in costs from building houses to comply with the 1993 MEC instead of a baseline of current practice in Colorado.

Benefits that accrue to the general population are not included in this report. Those benefits potentially include a reduction in air pollution, lower rates on utilities because of the deferral of new power plant construction, and increased economic and energy self-sufficiency for the state.

This subsection presents the costs and benefits of building to the 1993 MEC for the six cities analyzed. The overall results are shown in terms of first cost, mortgage cost impacts, energy cost impacts, and the impact of these various costs over time (years to positive cash flow and life-cycle cost [LCC] impacts). This allows numerous points of view to be expressed in this report.

The first cost is the incremental retail cost to purchase and install energy features in the home (e.g., the cost to buy and install more insulation). This cost includes the homebuilder's profit. This is the cost that would be paid if the home were paid for in cash.

Figure 2 compares the increase in first costs (assuming no mortgage) from the construction changes needed for compliance with the 1993 MEC. The 1993 MEC will increase first costs more in colder climates because the 1993 MEC is more stringent in these locations. In part, this reflects the assumption that current practice across Colorado is uniform. Most of the first cost increase from the 1993 MEC is attributable to the addition of basement-wall insulation and the use of windows that are more energy efficient.

Because most homes are financed, the financial impacts of the 1993 MEC on mortgages will likely be of significant interest to the consumer. This report deals with a financially limited home buyer making a relatively small down payment (10\% of the loan amount). Mortgage payments are constant over the period of the mortgage, and the portion of payments that is interest is assumed to be deducted from income taxes. An adjustable-rate mortgage might result in different costs to the home buyer, but this type of mortgage is not examined here because there are so many variations and future interest rates are impossible to predict. 


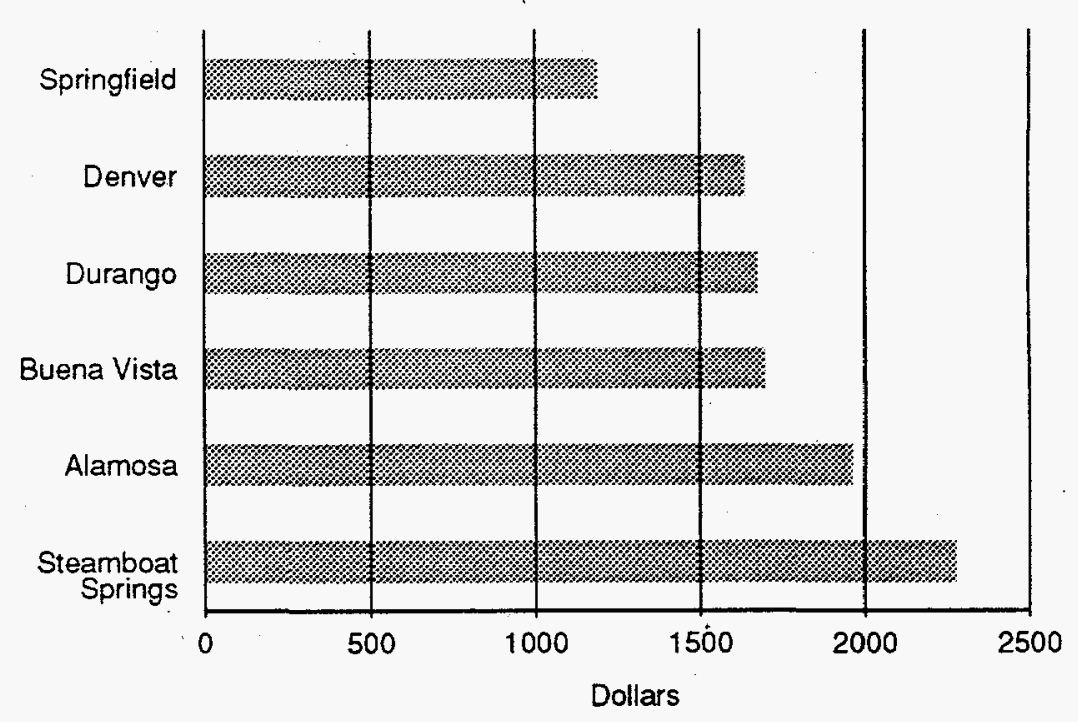

Figure 2. First Cost Impacts

Table 1 shows how the first cost increases will impact mortgage-related costs for a 30 -year fixed-rate mortgage with a $10 \%$ down payment. The up-front costs include the down payment, points, and loan fees. The increase in mortgage payments will not change over time because the mortgage payments are constant. The savings from income tax deductions of the mortgage interest will slowly decrease over time, the tax savings shown in Table 1 are for the first year.

Table 1. Impacts of Mortgage Costs

\begin{tabular}{||c|c|c|c|c|c|c|}
\hline & \multicolumn{6}{|c|}{ Cost Change Per Housing Unit } \\
\cline { 2 - 7 } & $\begin{array}{c}\text { Spring- } \\
\text { field }\end{array}$ & Denver & Durango & $\begin{array}{c}\text { Buena } \\
\text { Vista }\end{array}$ & Alamosa & $\begin{array}{c}\text { Steamboat } \\
\text { Springs }\end{array}$ \\
\hline \hline $\begin{array}{l}\text { Annual mortgage } \\
\text { payment increase } \\
\text { Down payment } \\
\text { increase } \\
\begin{array}{l}\text { First year tax } \\
\text { deduction savings }\end{array}\end{array}$ & $\$ 98$ & $\$ 135$ & $\$ 138$ & $\$ 140$ & $\$ 162$ & $\$ 187$ \\
\hline
\end{tabular}

Energy Cost Savings
A reduction in the energy costs (i.e., the homeowner's utility bills for heating and cooling) is the major benefit of any energy-efficiency standard. The intent of the 1993 MEC is to "enable effective use of energy in new building construction." The $1993 \mathrm{MEC}$ has requirements that are intended to keep energy use (and thereby energy costs) to a reasonably low level. The first-year energy cost savings as reported here reflect the savings in the homeowner's energy bills. 
Figure 3 shows the estimated annual energy cost savings resulting from the increased level of energy efficiency required by the $1993 \mathrm{MEC}$. As might be expected, the energy cost savings from the 1993 MEC are much larger in the colder climates than in the milder climates. Note the annual energy cost savings in Figure 3 are for the initial fuel prices. The energy cost savings are expected to increase in the future as energy prices go up. Most of the energy cost savings are from heating-season energy savings. The savings in cooling costs for Springfield and Denver (the only cities assumed to have air conditioning) are relatively small because 1) thermal improvements to the envelope only modestly reduce cooling costs and 2) cooling costs are relatively low.

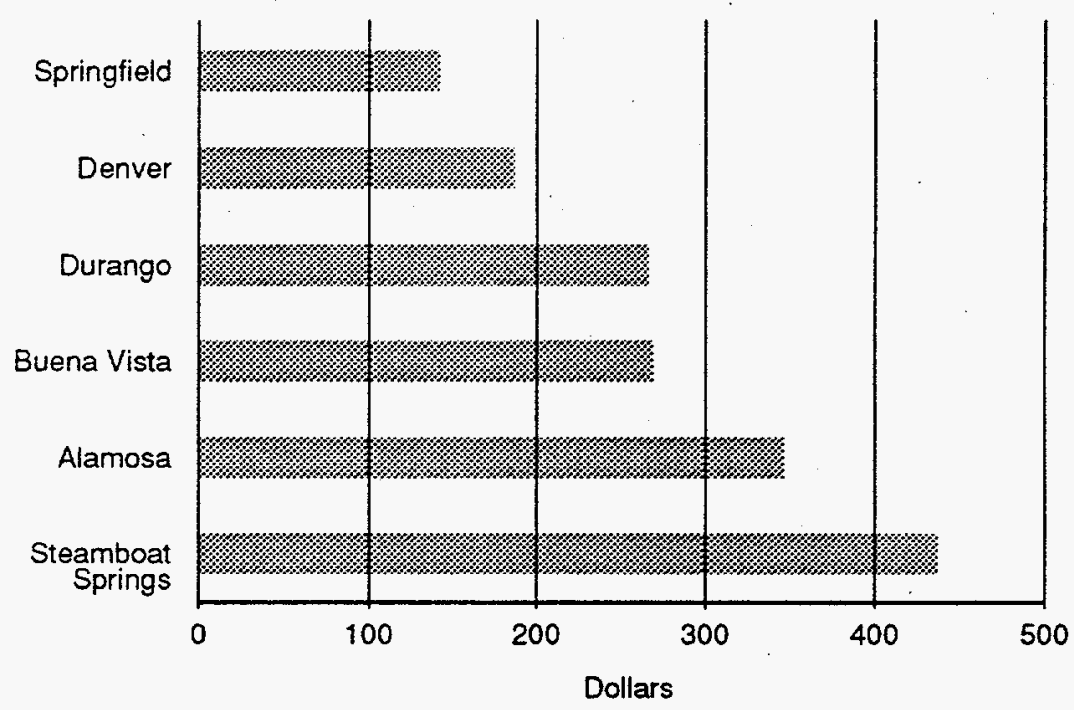

Figure 3. Energy Cost Impacts

Time to Positive Cash Flow
Most consumers want to know when they will start saving money (accounting for all costs and benefits). Of course, the energy cost savings resulting from increased energy efficiency start as soon as the home is occupied. Of more interest may be the time when the consumer has saved more money than he or she has paid out. This is referred to as the time to positive cash flow. Beyond this time, the net cost savings can be expected to continue to grow. The shorter this length of time to positive cash flow, the more attractive investing in increased energy efficiency becomes.

Figure 4 shows the number of years until the homeowner realizes a net cost savings from the increased levels of energy efficiency (i.e., the cumulative savings exceed the cumulative expenditures). This length of time was derived from the calculation of the up-front costs, the annual mortgage payments, energy costs, property taxes, and mortgage interest tax deductions. For example, during the third year of ownership, a homeowner in Denver would have saved more money than expended, and the savings would continue to grow after that time (more information on cash flow over time is given in the next subsection). 


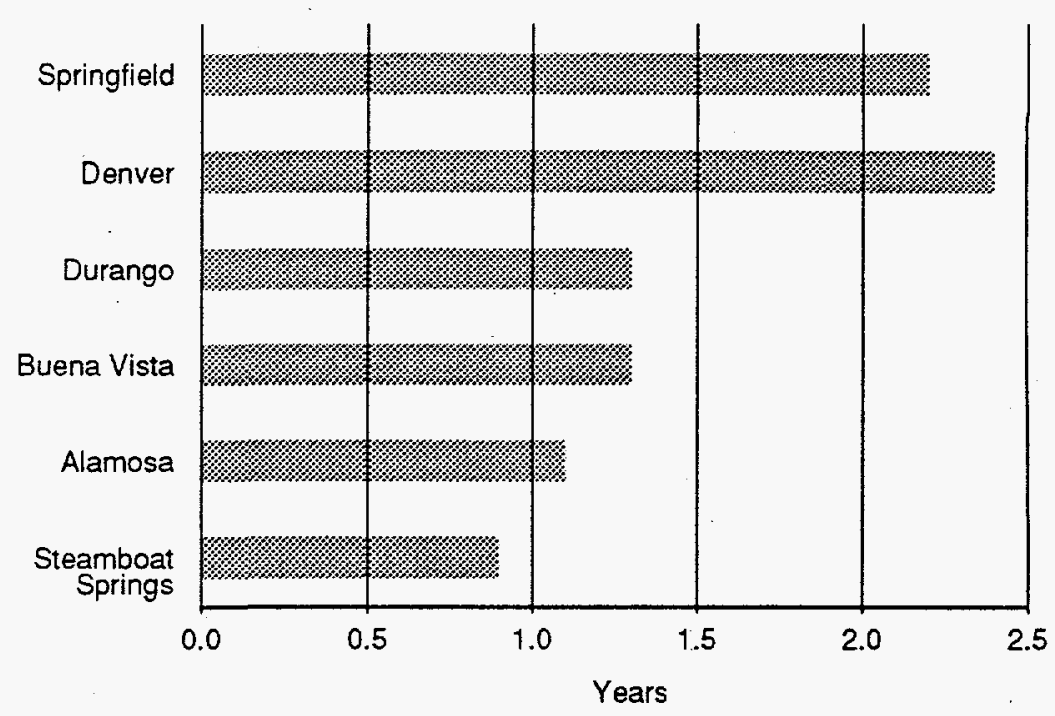

Figure 4. Years to Positive Cash Flow

Table 2 shows the net present value of all costs and benefits over the 30 -year period of analysis. A positive number indicates the homeowner's energy-related costs have gone down. This table also shows the benefit-tocost ratio, which is simply the ratio of the present value of the energy savings to the first cost (not accounting for a mortgage or taxes). In general, the benefit-to-cost ratio increases as the cities become colder. Denver is the exception because it has low fuel prices, reducing the energy cost savings benefit.

Table 2. Life-Cycle Cost Impacts

\begin{tabular}{||l|c|c|c|c|c|c||}
\hline & \multicolumn{6}{|c|}{ Cost Change Per Housing Unit } \\
\cline { 2 - 7 } & $\begin{array}{c}\text { Spring- } \\
\text { field }\end{array}$ & Denver & Durango & $\begin{array}{c}\text { Buena } \\
\text { Vista }\end{array}$ & Alamosa & $\begin{array}{c}\text { Steamboat } \\
\text { Springs }\end{array}$ \\
\hline \hline $\begin{array}{l}\text { Life-cycle cost } \\
\text { savings } \\
\begin{array}{l}\text { Benefit-to-cost } \\
\text { ratio }\end{array}\end{array}$ & $\$ 1772$ & $\$ 2220$ & $\$ 3753$ & $\$ 3791$ & $\$ 5116$ & $\$ 6614$ \\
\hline
\end{tabular}

Housing Affordability
This subsection presents a discussion of housing affordability (i.e., how the 1993 MEC would affect qualifying for a mortgage and cash flow for the home buyer). Many organizations and individuals are concerned about housing affordability. The nature of this concern varies, though there are two general aspects of the affordability issue. The first emphasizes either low first cost for residences by keeping costs down, so that buyers are able to qualify for loans to purchase homes; or adjusting existing lending 
practices, so that decreased energy costs from energy-efficient homes are reflected in the purchaser's ability to qualify for a larger loan. The biggest concern is often with the first time (new home) buyer and how the additional first cost for higher energy efficiency will eliminate some prospective buyers from qualifying for loans. There is also some concern that the first buyer will not receive a fair return on the energy-efficiency investment on resale.

The second aspect of the affordability issue emphasizes minimizing total costs, including purchase costs and operating costs. The objective is to minimize the sum of the costs of owning the home, including both energy costs and mortgage costs for energy-efficiency improvements. This longer term focus captures the benefits of energy efficiency over the home's lifetime. Nonmarket costs or impacts of energy consumption, such as environmental externalities, are sometimes included as costs. Some might also want to add market externalities by including social costs of fuel consumption not reflected in the market (e.g., including the impact of increased fuel use on the environment, reflecting marginal costs of new power sources, reflecting the higher-than-average capacity charge associated with heating, ventilating, and air-conditioning loads, and/or adding national balance-ofpayments cost).

A simple method of looking at the costs and benefits of higher energy efficiency over time is by studying the cash flow. Figure 5 shows the cumulative cash flow for a typical first owner of a single-family home in Denver. The figure shows the cash flow for a home built to the efficiency levels required by the 1993 MEC relative to a home built to typical current practice. A 30-year mortgage and a 10\% down payment were assumed. The owner was assumed to sell the house after 7 years, at which time the mortgage was terminated. The results shown in Figure 5 are for a home with a natural gas furnace, while the general results earlier in this section

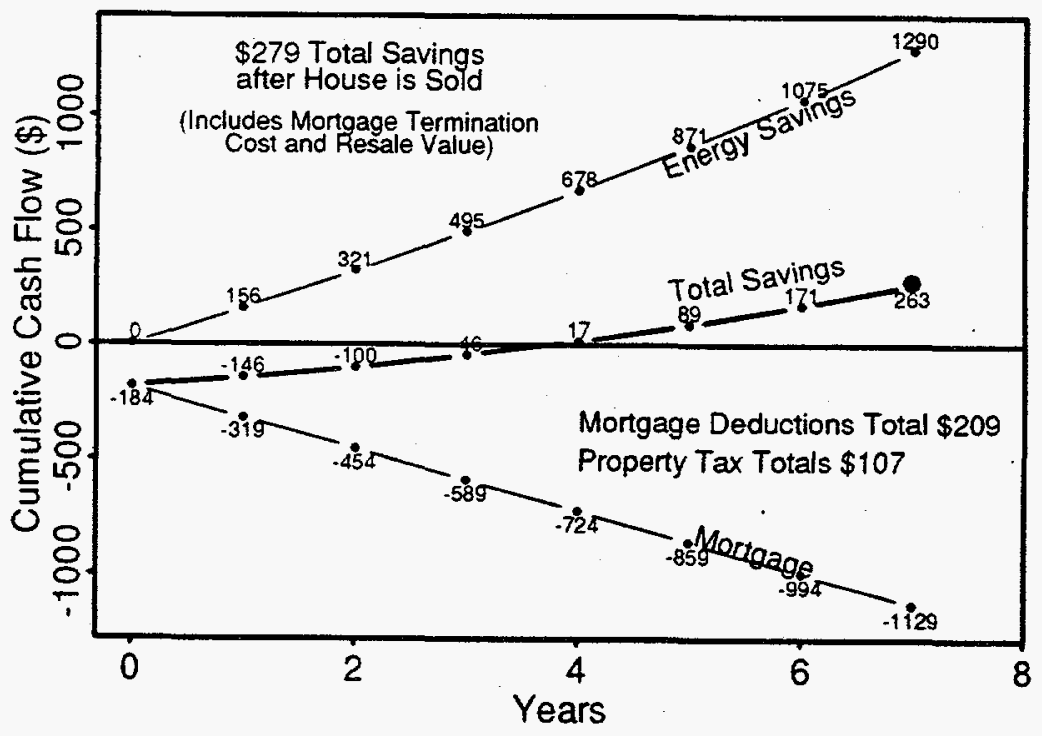

Figure 5. Typical Cash Flow for the First Owner of a Single-Family Home 
are weighted averages across several heating-fuel types (see page 26 for information about fuel averaging). At the time of the purchase, there was a cost of $\$ 184$ to cover the increased down payment and other up-front cost increases. Because the energy cost savings exceed the mortgage payment increases, the net cash flow for each year is positive (excluding the first year, which has the up-front costs). The cumulative cash flow becomes positive during the third year and continues to grow in all future years. At the end of 7 years when the house is sold, the estimated resale value related to the additional investment in energy efficiency exceeds the mortgage termination cost of this same investment by $\$ 16$. Note that any future owner will also quickly obtain a positive cash flow. The cash flow for future owners is likely to be even more favorable, assuming a lower purchase cost (of the energy-efficiency measures) and the forecasted higher fuel costs.

The concern that home buyers will be eliminated from qualifying for a mortgage by the higher first costs associated with higher levels of energy efficiency must be addressed by reflecting the increased financial viability of the home buyer in the mortgage process. In cases where the cost of energy improvements themselves may disqualify buyers from home loans, lenders need to use a mortgage qualification criterion that takes into account the fact that the owner is actually financially stronger from a more energyefficient home and, therefore, better able to pay the energy-efficient home mortgage than the non-energy-efficient home mortgage. Although energyefficient mortgages have been around in some form for a long time, they are seldom used. Therefore, an effort should be made to introduce viable methods of reflecting the home buyer's stronger financial situation in energy-efficient-lending criteria. The best way to address the effects of energy-efficiency improvements on the price of a home is to adjust the lending criteria rather than to reduce the purchase price by backing off the energy-efficiency levels. The positive cash flow and the short time to positive cash flow argue that building homes to comply with the $1993 \mathrm{MEC}$ are clearly in the interest of the home buyer.

A similar situation exists in the rental market. This is especially true when prices are fixed by governmental agencies, such that the building investor/ owner/manager is not able to pass the additional cost of energy efficiency to the occupant (assuming the occupant gets the benefits of lower energy bills). Builders and owners of multifamily housing should be allowed to profit on the construction and management of energy-efficient housing.

The number of buyers impacted by the increased first cost can be estimated. The National Association of Home Builders (NAHB) estimated that a home cost increase of $\$ 1680$ required an additional $\$ 570 /$ year in buyer income (at $10 \%$ down) and disqualified $2.5 \%$ of the potential home buyers (Consumers' Research 1991). For Denver, this was scaled back to the estimated increase in first cost, $\$ 1636$, producing an estimate that the energyefficiency standards would require an additional $\$ 555$ in family income and disqualify approximately $2.4 \%$ of the potential new home buyers. This calculation assumed that no credit was given in the mortgage process for reduced expenses resulting from a reduction in energy costs and that the 
home buyer does not cut expenses elsewhere in the cost of the residence. In the aggregate, the $97.6 \%$ of home buyers who can afford the price increase would be better off.

The definition of "affordable" energy-efficiency standards offers a goal for changing lending practices to eliminate the impact of increased energyefficiency requirements on the ability to qualify for a mortgage. In its resolution, NAHB (1992a) defines increases in thermal performance standards to be affordable if "A buyer of a home who qualifies to purchase the home before the addition of the thermal performance standards would still qualify to purchase the same home after the additional cost of the energysavings construction features ..."

Because the home buyers' total expenses are less under the 1993 MEC, a stronger financial position results. In the absence of a procedure that considers the benefit of the energy efficiency in the mortgage qualification process, some buyers may be forced to accept a slight downgrade or, at the extreme, may not be able to afford a new home; however, the number of buyers impacted should be small. Additionally, the lending industry is moving in the direction that will give credit to energy-efficiency investments. Further work is needed to make energy-efficiency mortgages a reality for those who might be disqualified from a loan based on the added cost of energy efficiency. If and when energy-efficiency mortgages become common, home buyers should be as able to qualify for mortgages for highly efficient houses as for less-efficient houses. 


\section{Life-Cycle Costing}

\section{Methodology}

For this analysis to be credible, the parameters used must properly reflect present or expected market conditions. Details on the parameters selected are given here and the subsections that follow. The first of the parameters refers to the methodology and analytical tools used to perform the analysis. This section contains a description of those components of the analysis.

The LCC analyses are used to compare the present value of total long-run costs associated with several alternative courses of action. The general approach of the LCC method is to sum the costs and benefits of an investment, which, in turn, are calculated based on existing and forecasted economic parameters. Costs and benefits that will occur in the future are discounted to present values. Discounting is the lowering of the value of future costs and/or benefits to account for the value that individuals put on having money now versus in the future.

The basic cost elements of the generic LCC method for energy-efficiency investments are shown below. All costs and benefits are computed in present-value dollars.

Life-cycle cost $=$ first costs + energy costs + maintenance costs - resale value

The first two elements were introduced in the previous section. Because most home buyers obtain a mortgage, the first costs are spread out over the mortgage period and the up-front costs are limited to the down payment and mortgage fees. As down payments are often a small percentage of the first cost, the initial cost impact of increased investments in energy efficiency is much lower than the first cost. Mortgages have the important feature that interest on the mortgage is tax deductible.

The third element of the equation, maintenance costs, represents the outlays required to maintain the investment following its purchase. This represents the maintenance, repair, or replacement expenses required for the EEMs. For the envelope measures examined in this analysis, the maintenance costs are zero.

The final element of the equation is the resale or salvage value of the investment at the end of the analysis period. The EEM values depreciate, based on the straight-line method, so the resale value at the end of the period of analysis is equal to the nominal value of the EEM multiplied by the remaining fraction of the EEM lifetime.

The economic analysis was done with the Automated Residential Energy Standard (ARES) program. The ARES software is a computer program developed for the U.S. Department of Energy that contains an LCC methodology for residential energy-efficiency decisions (Lortz and Taylor 
1989). Given a set of fuel-price, financial, economic, and EEM cost parameters for a building at a specific location, ARES identifies the economic impacts of incremental improvements in energy efficiency. ARES considers both space heating and cooling, and was designed specifically for the development of residential energy-efficiency standards.

In addition to an LCC model, ARES incorporates an energy database produced by a simulation model, allowing it to estimate the energy use for a specific selection of EEMs. The energy usage associated with each combination of EEMs becomes an input to the ARES economic analysis. The incorporation of an energy simulation in ARES removes the requirement for doing separate building energy simulations. The ARES energy simulation is a parameterization of a large database of DOE-2 simulations (DOE 1989a) (DOE-2 is a sophisticated energy analysis software commonly used to estimate building energy consumption). 


\section{Financial, Economic, and Fuel-Price Parameters}

In this section, the financial, economic, and fuel-price-parameter values necessary for the cost/benefit analysis of the $1993 \mathrm{MEC}$ are specified, justified, and documented. Most of the financial, economic, and fuel-price parameters required for input to this analysis are summarized below. These parameters represent the costs and benefits from the homeowner's perspective.

- new home mortgage parameters

- mortgage interest rate ( $8.0 \%$ nominal, assuming $3.9 \%$ inflation)

- points and loan fees ( $1.6 \%$ of the mortgage amount)

- loan term (30 years)

- down payment $(10 \%)$

- mortgage insurance (3.5\% of mortgage)

- other rates and economic parameters

- alternate investment rate (discount rate) $(4.0 \%$ real or approximately $8.1 \%$ nominal, assuming $3.9 \%$ future inflation)

- marginal federal plus state income tax rates (26\% average)

- period of analysis (30 years)

- building life (50 years)

- residential fuel prices by city and annual escalation rates

- electricity ( $1.2 \%$ escalation)

- natural gas (1.6\% escalation).

In choosing the parameters for this analysis, the intent was to identify and document the best source available for each parameter. Most of the parameter values are commonly reported statistics and are traceable to published sources. Some of the data was provided by the Colorado Office of Energy Conservation. It should be noted that some of the parameter values vary across time, locations, markets, institutions, circumstances, and/or individuals. In general, the mean or median value was taken for any particular parameter. If multiple sources for a single parameter were identified, an attempt was made to choose the best source, with a preference toward the most respected, most recent, and published sources.

Financial Parameters

Because most home buyers obtain a mortgage, the economic analysis accounts for a mortgage. A mortgage interest rate of $8.0 \%$ was selected for this analysis, based on long-term U.S. Office of Thrift Supervision historical real averages using 1963-1991 data (OTS 1991). Points and loan fees were determined from the same data to average $1.6 \%$ of the mortgaged amount; this cost was assumed to be split equally between points (tax deductible) and loan fees (not tax deductible). This long-term rate is also close to current mortgage rates. 
An average of 26 years until the loan reaches maturity for fixed-rate mortgages has been reported (OTS 1991). This average term indicates that a 30 -year mortgage term is likely the most typical; therefore, 30 years was used as the loan term for this analysis.

The loan-to-price ratio for conventional, fixed-rate, single-family home mortgages is reported as $74.4 \%$ for 1991 (OTS 1991). A similar value is reported by a mortgage insurance company in the U.S. Department of Commerce's Statistical Abstract (DOC 1991a). The National Association of Realtors reports the median down payment of $12 \%$ for all home buyers who finance their purchase (NAR 1992). However, a lower rate of $10 \%$ was used in this analysis to represent the lower down payments commonly paid by financially limited home buyers.

Private mortgage insurance is normally required for loans with low down payments. Based on data provided by a mortgage company, NAHBdeveloped data (NAHB 1992b), and the various types of loans and down payments commonly available, average private mortgage insurance costs were calculated. Private mortgage insurance was included as a non-taxdeductible cost to the home buyer, fixed at $3.5 \%$ of the mortgage loan amount, and included in the mortgage payments.

\section{Alternate Investment Rate (Discount Rate)}

\section{Inflation Rate}

An analysis of EEMs must convert costs and benefits occurring in future years into present-value dollars. To convert future dollars into present dollars, an alternate investment rate or discount rate needs to be established.

Using the criterion that the alternate investment rate should be based on costs to the buyer using the next best alternate investment opportunity, the best rate of return commonly available is mortgage prepayment, yielding a real return of approximately $1.5 \%$ to $4.0 \%$. This range was selected as the possible range for the discount rate for this analysis. Because the long-term treasury bond rates for recent years is within this range, this real discount rate of $4.0 \%$ (8.1\% nominal, if a $3.9 \%$ inflation rate is included) was used in this analysis. The selection of the alternate investment rate is described in detail in the Appendix.

The inflation rate is used to convert between nominal and real rates. An inflation rate of $3.9 \%$ was used. This projected rate is from the Annual Energy Outlook 1993 (EIA 1993) and is equal to the average forecast of four other sources.

A period of analysis equal to the mortgage term of $\mathbf{3 0}$ years was used in this analysis. This is consistent with the Congressional guidance contained in the conference report on the Energy Policy Act legislation (CRH 1992) that states that if an LLC analysis is conducted, it "should use a $\mathbf{2 5}$ or 30 year term to reflect the fact that houses have long useful lives and are commonly financed through 30 year mortgages." The discount rate $(4.0 \%$ 
Property Tax Rate

Income Tax Rate

Fuel-Price Parameters

Fuel-Price Data real) diminishes the value of future dollars such that periods far into the future do not have a major impact on this analysis (e.g., the effect of the difference between analysis periods of 30 years and 50 years is small).

A 50-year building life for homes was assumed for this analysis. The life affects the resale value at the end of the 30 -year analysis period. No references were found that give median building lives, but the 1989 American Housing Survey (DOC 1991b) reports that 31\% of all existing housing units are 50 years or older. This indicates housing commonly lasts at least 50 years.

For this analysis, there was assumed to be a property tax of $1.1 \%$ of the home value. Therefore, the homeowner must pay $1.1 \%$ of the increase in first costs from the higher levels of energy efficiency resulting from compliance with the $1993 \mathrm{MEC}$. The tax rate for Colorado was determined from an article in Money (1992).

The marginal income tax rate paid by the homeowner determines the value of the mortgage tax deduction. The homeowner is assumed to itemize deductions, which is most common. Data on household incomes for all purchasers of homes were obtained from the Internal Revenue Service (1992) and the NAR (1992). These data were used to estimate federal tax deductions for the average homeowner. Approximately half of all home buyers were in the $28 \%$ bracket and half were in the $15 \%$ bracket. Therefore, $21 \%$ was used to represent the weighted average income tax rate. Accounting for an estimated average state income tax of $5 \%$, the total income tax rate is $26 \%$.

Both current fuel prices and fuel-price-escalation rates in the future were required for this analysis.

Residential energy prices obtained by the Colorado Office of Energy Conservation from the applicable utilities were used in this analysis and are shown in Table 3.

Table 3. Fuel Prices by City

\begin{tabular}{|l|c|c||}
\hline \multicolumn{1}{|c|}{ City } & $\begin{array}{c}\text { Natural Gas } \\
(\$ / \text { therm })\end{array}$ & $\begin{array}{c}\text { Electricity } \\
(\$ / \mathrm{kWh})\end{array}$ \\
\hline \hline Springfield & 0.478 & 0.0693 \\
Denver & 0.414 & 0.0657 \\
Durango & 0.486 & 0.0740 \\
Buena Vista & 0.422 & 0.0808 \\
Alamosa & 0.442 & 0.0657 \\
Steamboat Springs & 0.470 & 0.0697 \\
\hline
\end{tabular}


From the consumer's perspective, the energy cost savings from changes in energy-efficiency levels are driven by marginal fuel prices, which may not equal average fuel prices. For example, utilities often charge a lower rate per kilowatt hour of electricity for additional electricity consumed beyond some minimum threshold--the marginal rate is this lower rate. Fuel taxes were estimated to average $5.0 \%$. The fuel prices in Table 3 are the marginal prices used in this analysis.

Fuel prices in Colorado are well below average residential fuel prices for the United States, which are \$0.63/therm and \$0.084/kWh (EIA 1995).

Fuel-Price-Escalation Rates

The residential fuel-price-escalation rates (real) displayed in Table 4 were taken from projections published annually (NIST 1994). The fuel-priceescalation rates for each fuel type are projected by census region for 30 years into the future. The fuel-price-escalation rates for the region Colorado is located in were used in this analysis.

Table 4. Residential Fuel-Price-Escalation Rates, 1995 through 2024

\begin{tabular}{|l|c|}
\hline \multicolumn{1}{|c|}{ Fuel } & $\begin{array}{c}\text { Escalation Rate } \\
\text { (\% Real) }\end{array}$ \\
\hline \hline Electricity & 1.2 \\
Natural gas & 1.6 \\
\hline
\end{tabular}




\section{Energy-Efficiency Measures}

The analysis to determine the cost effectiveness of the 1993 MEC in Colorado requires information on specific EEMs. This section primarily documents the characterization of the EEM options used in this analysis, including the levels ( $R$-values for the ceilings, above-grade opaque walls, and basement walls; U-values for windows), costs, and some of the construction assumptions.

Thermal-Envelope EnergyEfficiency Measures
This analysis considers the cost effectiveness of the 1993 MEC thermalenvelope requirements. The envelope components considered in this analysis are ceilings, above-grade opaque walls, windows, doors, and basements with wall insulation. The selection of full basements as the foundation type was approved by the Colorado Office of Energy Conservation. For each component, EEMs corresponding to current construction practice and to 1993 MEC compliance were determined. Table 5 shows these EEMs.

Table 5. Energy-Efficiency Measures for Current Practice and 1993 Model Energy Code

\begin{tabular}{|c|c|c|c|c|}
\hline & $\begin{array}{l}\text { Ceiling } \\
\text { Insulation }\end{array}$ & $\begin{array}{c}\text { Wall } \\
\text { Insulation }\end{array}$ & Window Type & $\begin{array}{l}\text { Basement } \\
\text { Insulation }\end{array}$ \\
\hline Current practice & $\mathbf{R}-30$ & R-11 & Double aluminum & None \\
\hline \multicolumn{5}{|l|}{$1993 \mathrm{MEC}$} \\
\hline Springfield & $\mathrm{R}-38$ & $\begin{array}{l}\mathrm{R}-13 \text { batt }+ \\
\mathrm{R}-4 \text { rigid }\end{array}$ & $\begin{array}{l}\text { Good double } \\
\text { aluminum or } \\
\text { poor double vinyl } \\
\text { or wood }\end{array}$ & R-11 \\
\hline Denver & R-38 & $\begin{array}{l}\mathrm{R}-13 \text { batt }+ \\
\mathrm{R}-4 \text { rigid }\end{array}$ & $\begin{array}{l}\text { Double vinyl } \\
\text { or wood }\end{array}$ & R-11 \\
\hline Durango & R-38 & $\begin{array}{l}\mathrm{R}-13 \text { batt }+ \\
\mathrm{R}-4 \text { rigid }\end{array}$ & $\begin{array}{l}\text { Double vinyl or } \\
\text { wood, } \\
\text { with low-E }\end{array}$ & R-11 \\
\hline Buena Vista & $\mathrm{R}-38$ & $\begin{array}{l}\text { R-13 batt }+ \\
R-4 \text { rigid }\end{array}$ & $\begin{array}{l}\text { Double vinyl } \\
\text { or wood, } \\
\text { with low-E }\end{array}$ & $\mathrm{R}-11$ \\
\hline Alamosa & R-38 & $\begin{array}{l}R-13 \text { batt }+ \\
R-7 \text { rigid }\end{array}$ & $\begin{array}{l}\text { Double vinyl } \\
\text { or wood, } \\
\text { with low-E }\end{array}$ & R-11 \\
\hline Steamboat Springs & R-38 & $\begin{array}{l}\mathrm{R}-13 \text { batt }+ \\
\mathrm{R}-7 \text { rigid }\end{array}$ & $\begin{array}{l}\text { Double vinyl } \\
\text { or wood, } \\
\text { with low-E } \\
\text { and argon }\end{array}$ & $\mathrm{R}-11$ \\
\hline
\end{tabular}


Current practice was provided by the Colorado Office of Energy Conservation. This represents typical construction practice for Colorado-many houses are built to be more energy efficient or less energy efficient than the levels assumed here.

The 1993 MEC generally specifies thermal-envelope requirements in terms of overall U-value, which is called the $\mathrm{U}_{0}$-value. A U-value is the inverse of the R-value, and a lower U-value represents higher energy efficiency. The $U_{0}$-value accounts for all materials in the component, including gypsumboard, framing, insulation, and siding. Components include ceilings, above-grade walls, and various foundation types. The $1993 \mathrm{MEC}$ does not specify window, door, or opaque wall thermal requirements individually, but rather specifies gross wall $\mathrm{U}_{0}$-value requirements.

It should be noted that compliance with the 1993 MEC can be based on meeting individual component $\mathrm{U}_{\mathrm{o}}$-value requirements, an equivalent overall building $\mathrm{U}_{0}$-value (as was done for this analysis), or an energy equivalent based on a whole-building energy analysis. Thus, a number of alternative EEM combinations would lead to compliance for any particular home. Builders would be free to use any type of construction that complied with the $1993 \mathrm{MEC}$ component $\mathrm{U}_{\mathrm{o}}$-value, overall $\mathrm{U}_{\mathrm{o}}$-value, or energy-based performance requirements. For this analysis, complying packages of EEMs shown in Table 5 were selected utilizing software known as MEC HECKK $^{\text {ns }}$ (PNL 1994), which notifies the user if a set of EEMs complies with the 1993 MEC and allows tradeoffs across all building components. ${ }^{\text {(a) }}$

Combinations of EEMs other than those shown in Table 5 could also be selected. For one example, in Denver, if the windows have low-emissivity (low-E) coatings, the wall insulation can be reduced to R-11 batt insulation with no rigid insulation. If the heating, ventilating, and air-conditioning equipment efficiencies are above the minimums assumed in this analysis (i.e., the minimums allowed by law), reductions in the energy efficiency of the envelope levels may be possible. It should also be noted that compliance with the $1993 \mathrm{MEC}$ is affected by envelope-component dimensions of the house (for a description of the house analyzed here, see subsection entitled Prototype Single-Family Home).

(a) At the time this analysis was conducted, MEC CHECK ${ }^{\text {Tr }}$ software was available only for the 1992 MEC, not the 1993 MEC. However, for single-family homes in Colorado climates, the 1992 MEC and 1993 MEC thermal-envelope measures are equivalent. 
Energy-Efficiency Measure Costs

Ceilings
Having established envelope-component EEMs for current practice and the 1993 MEC (see Table 5), the next step was to determine construction costs for each of these EEMs. The costs that are relevant to the outcome of this economic analysis are the incremental costs (i.e., the cost of the change required for the improvement in energy efficiency to move from current practice to the levels needed for 1993 MEC compliance). The incremental costs include costs of general construction changes required to accommodate an energy-efficiency change (e.g., walls with $R-19$ batt insulation require 2-by-6 studs instead of 2-by-4 studs). All costs in the tables in this section represent retail costs to the home buyer/owner. These costs include materials, installation, and markups for overhead and profit. Cost data from sources outside of Colorado were modified to account for regional cost differences using location factors (Means 1994). These factors lowered national prices 3\% for Denver, $7 \%$ for Springfield, and 10\% for Alamosa, Buena Vista, Durango, and Steamboat Springs (the multipliers were not provided in Means [1994] for Springfield, Buena Vista, and Steamboat Springs, so multipliers for nearby locations were used). Although these location adjustments are not included in the costs shown in the following subsections, they were included in this analysis. Costs from older sources were inflated to current conditions based on the residential construction cost inflation rate (DOC 1994). In an attempt to corroborate the cost data used here with local Colorado costs, the insulation cost data were compared to cost data provided by Mr. Randy LaFon, Sutton Insulation, Lakewood, Colorado. In most cases, the costs were similar. Some EEMs were ultimately not included in the economic analysis (see Table 5) because they were more costly than other options.

Component $\mathrm{U}_{\mathrm{o}}$-values are also presented in the following subsections. $\mathrm{U}_{\mathrm{o}}$-values affect compliance with the $1993 \mathrm{MEC}$ and relate closely to energy use. The $U_{0}$-values used here were determined using material thermal properties and calculation techniques recommended by the American Society of Heating, Refrigerating and Air-Conditioning Engineers (ASHRAE 1989). Window $U_{0}$-values were obtained from tested window data.

Ceilings were assumed to have an attic space (i.e., vaulted ceilings/roofs were not considered). No skylights were assumed. Cost data for ceilinginsulation levels and construction assemblies were obtained from four national sources and one regional source:

- Means Residential Cost Data 1993 (Means 1992)

- 1992 National Construction Estimator (Craftsman 1992)

- An Economic Data Base in Support of SPC 90.2: Cost of Residential Energy, Thermal Envelope and HVAC Equipment (NAHB 1986) 
- California Energy Commission (Eley 1991).

Comprehensive costs for regular-density fiberglass batt insulation were available from all the sources. Less-complete data were available for blown insulation, with the NAHB the only comprehensive national source for blown insulation. A regional study of California costs (Eley 1991) reported blown insulation at much lower costs than NAHB costs. Other, lesscomprehensive, regional sources also reported that costs for blown insulation were at least as low as the NAHB costs, if not lower. Because blown insulation was found to be somewhat more cost effective than batt insulation, according to all the above sources, and is commonly used, blown insulation was assumed in this analysis. The NAHB blown insulation data were chosen for the analysis of ceilings with attics, even though they had the highest costs, because they were the only data of a national scope. The insulation cost used here was very similar to costs provided by Mr. Randy LaFon, Sutton Insulation, Lakewood, Colorado.

Figure 6 shows the costs versus U-value for the five different ceiling cost sources for ceilings with attics. Only R-30 and R-38 were used in the economic analysis. Note that all the insulation costs from different sources are reasonably close to each other, with the exception of the California costs, which are significantly lower. Table 6 shows the $U_{0}$-values and costs for roof/ceiling insulation R-values used in this analysis.

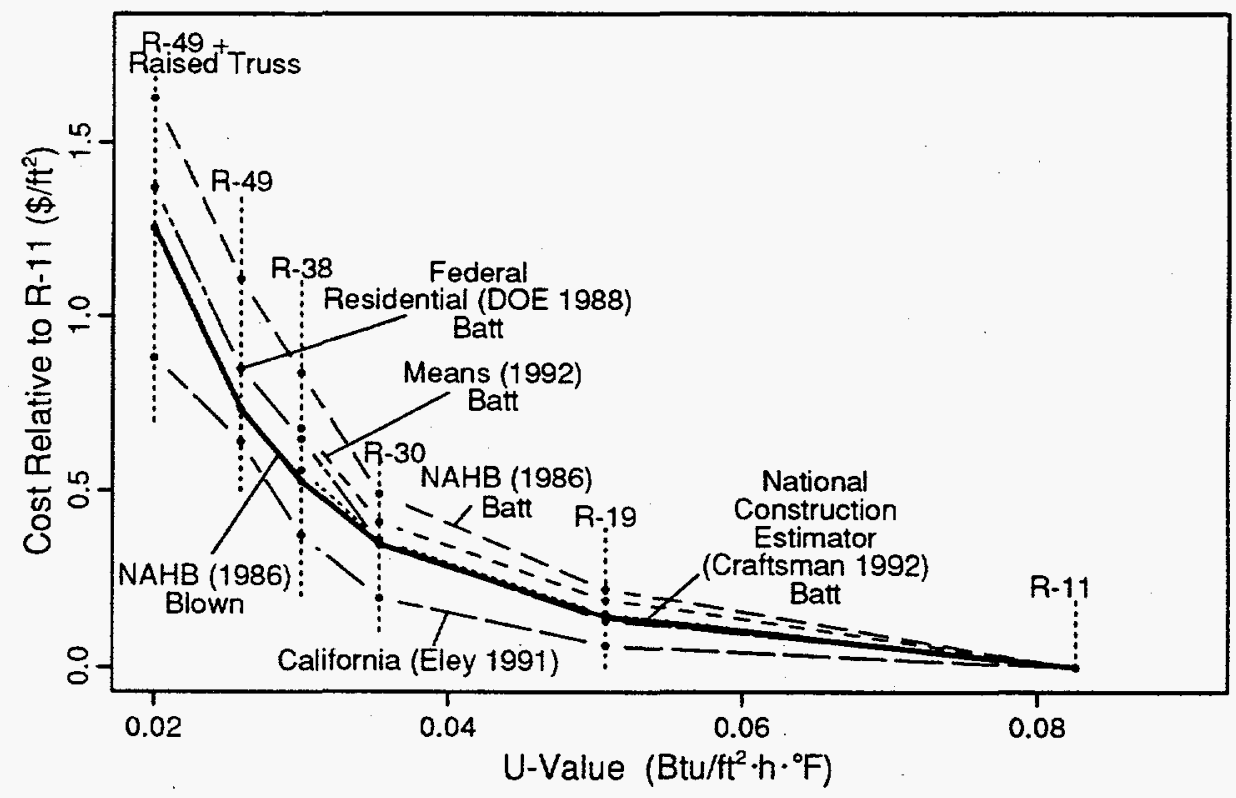

Figure 6. Ceiling Energy-Efficiency Measure Costs from Five Sources 
Table 6. Ceiling $\mathrm{U}_{0}$-Values and Costs

\begin{tabular}{|c|c|c|}
\hline Nominal R-Value & Ceiling $U_{\mathrm{o}}$-Value & $\begin{array}{c}\text { Cost Relative to } \\
\mathrm{R}-11\left(\$ / \mathrm{ft}^{2}\right)\end{array}$ \\
\hline \hline R-30 & 0.0353 & 0.30 \\
$\mathrm{R}-38$ & 0.0300 & 0.44 \\
\hline
\end{tabular}

Walls

Windows
The wall EEM assumed for current practice in Colorado was R-11 insulation in a 2-by-4 16-in. on-center framed wall with plywood sheathing (R-0.83). More energy-efficient EEMs that can be used to meet the 1993 MEC requirements include R-19 batt insulation; high-density $R-13, R-15$, and R-21 batt insulation; and foam sheathing insulation, such as polystyrene and isocyanurate.

The addition of up to $1 \mathrm{in}$. of foam sheathing is a commonly available option, as evidenced by the cost data (NAHB 1986; Barnett and Thor 1990; NAHB 1991a; Fryer and Schalch 1992; Means 1994). In fact, some builders use more than 1 in. of exterior sheathing (this is a method of achieving high R-values without the use of 2-by-6 walls). The use of more than 1 in. of exterior sheathing is not a widespread practice, however, and was not included as an EEM option. Walls with rigid foam insulation lack structural support and, therefore, need let-in corner bracing (NAHB 1988). These bracing costs were obtained from Means (1994) and were $\$ 0.13 / \mathrm{ft}^{2}$ of wall area for 16-in. on-center construction. Another construction option is to use walls with plywood at the corners instead of the let-in bracing, which decreases the energy efficiency of the wall slightly (plywood corner bracing was assumed in the wall U-value calculations).

Costs for changing from 2-by -4 to $2-b y-6$ framing to accommodate R-19 insulation were calculated. The cost data indicated that it is less expensive to meet the $1993 \mathrm{MEC}$ gross wall requirements by using 2-by-4 construction with R-11 or R-13 batt insulation and rigid sheathing insulation and energy-efficient windows rather than using 2-by-6 construction and $\mathrm{R}-19$ insulation.

Figure 7 shows the wall-insulation costs for various EEM levels. Note that not all of these insulation levels were used in the economic analysis.

Table 7 shows the wall EEMs, $U_{0}$-values, and cost increments used in this analysis in order of decreasing $\mathrm{U}_{0}$-value.

Window cost data were obtained in a different manner and from different sources than the other EEM cost data. The most important aspect of collecting window cost data is to correctly associate a cost and a $U_{0}$-value. Obtaining a cost-versus-energy-efficiency relationship is more difficult for windows because window costs are greatly affected by nonenergy characteristics, such as appearance. Obtaining window-efficiency costs is made more difficult by the relatively rapid changes in window technology and 


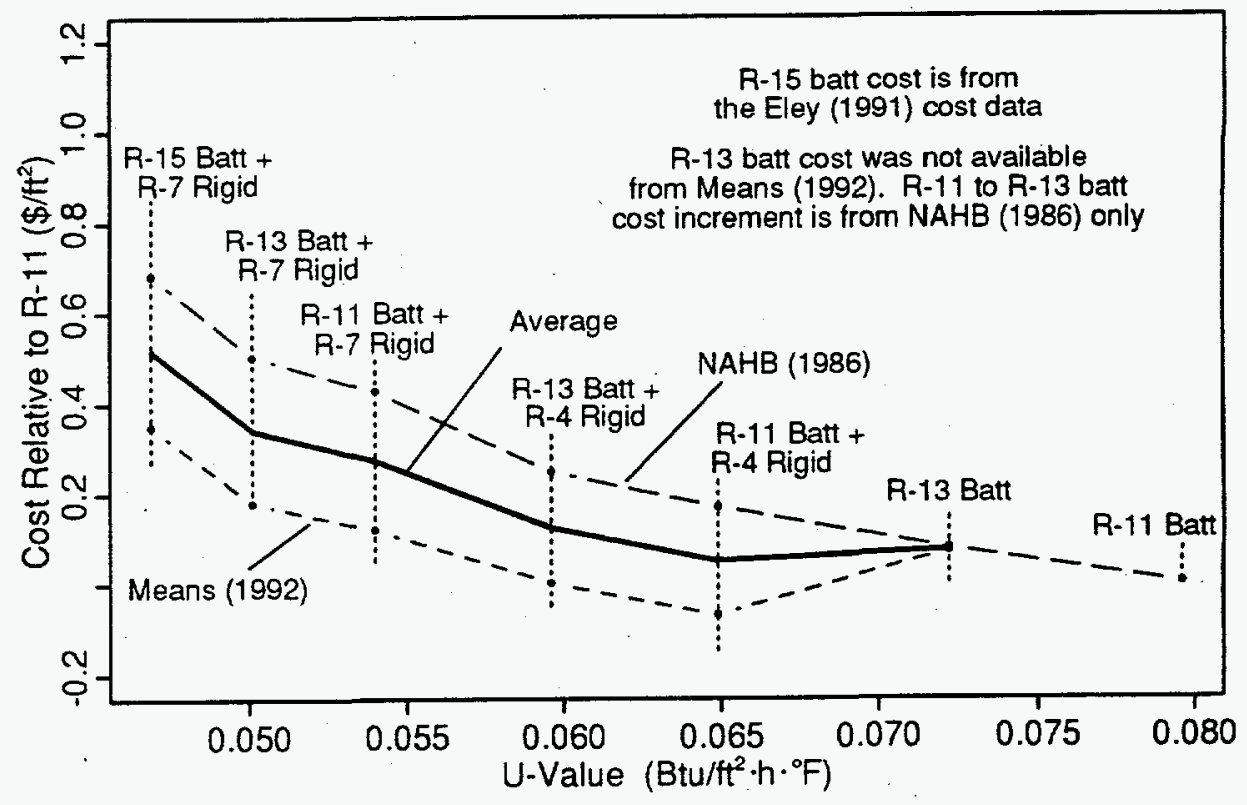

Figure 7. Wall Energy-Efficiency Measure Costs from Two Sources

Table 7. Wall $\mathrm{U}_{\mathrm{o}}-$ Values and Costs

\begin{tabular}{|c|c|c|c|}
\hline $\begin{array}{c}\text { Nominal Batt } \\
\text { Insulation R-Value }\end{array}$ & $\begin{array}{c}\text { Rigid Insulation } \\
\text { R-Value }\end{array}$ & $\begin{array}{c}\mathrm{U}_{\mathrm{o}}-\text { Value } \\
\text { of Wall }\end{array}$ & $\begin{array}{c}\text { Cost Relative to } \\
\mathrm{R}-11\left(\mathbf{\$} / \mathrm{ft}^{2}\right)\end{array}$ \\
\hline \hline 11 & 0.83 & 0.0825 & 0.00 \\
13 & 4 & 0.0593 & 0.12 \\
13 & 7 & 0.0499 & 0.34 \\
\hline (a) The R-value of 0.83 is for plywood sheathing. \\
\hline
\end{tabular}

energy-efficiency costs. In particular, vinyl framing, low-E coatings, and argon-filled windows are rapidly penetrating the market and are dropping in price.

Two sources of window cost data were judged to be the best available. The first was a survey of nine Pacific Northwest window manufacturers for the Washington State Energy Office (Byers 1990). The other source of window cost data was the work done for the California Energy Commission (Eley 1991). These two sources were used for a number of reasons. First, costs for a fairly extensive set of window types were available from multiple manufacturers from both of these sources. (In all cases, there were three or more manufacturers from each of the two sources for each window improvement option of interest.) The data included new energy-efficient technologies, such as vinyl sashes, low-E surfaces, and argon gas.

The examination, from an energy-efficiency standpoint, of windows currently on the market showed the range of costs and efficiencies for the 
most cost-effective windows with incremental prices for only a few energyrelated features. The window assumed for current practice was a doublepane, aluminum-frame window. The incremental changes in windows that needed costs were aluminum frame to aluminum with thermal break, vinyl, or wood frame; the addition of low-E coating; and the addition of argon gas. To isolate cost changes for improved energy efficiency, the cost changes for incremental window improvements, such as adding low-E, were determined separately for each manufacturer, so that cost changes were not aggregated across manufacturers until after the cost changes had been identified for each manufacturer. Examining window improvements by manufacturer tended to avoid the large variation in other window characteristics that affect price in intermanufacturer comparisons. The costs for any given incremental thermal improvement were assumed to be constant regardless of other thermal characteristics (e.g., the costs of adding a low-E coating to aluminum- and vinyl-framed windows were identical). The Washington and California costs for each window feature were averaged.

Current costs for low-E coatings were difficult to establish because of recent technology improvements. For this reason, the California (Eley 1991) or Washington (Byers 1990) cost data were not used, but an estimated cost that was lower was used. In the last few years, there has been a change in the commercially available low-E technologies. Of most interest here is the new "hardcoat" low-E coating, which is both better in performance and lower in price than older "hardcoat" technologies. This new low-E technology has begun to reach the market and was assumed to be the most cost-effective type of low-E coating. The cost of the new low-E coating to the glass manufacturer is low, approximately $\$ 0.50 / \mathrm{ft}^{2}$ (Gerhardinger and Flagg 1992). Based primarily on this manufacturer's cost, the retail cost (including overhead and profit) of the new low-E coating was estimated to be $\$ 1.00 / \mathrm{ft}^{2}$ to the consumer. The American Architectural Manufacturers Association (AAMA 1992) indicates that low-E coating is a widely used window option and is increasing, with residential market penetration rates up from $28 \%$ in 1988 to $31 \%$ in 1991 . At least one large window manufacturer (Andersen Windows, Bayport, Minnesota) has moved its whole line to low-E coating, providing evidence of the penetration of low-E coating in the market.

Evidence exists that vinyl-framed windows have gained acceptance in new residential construction. Vinyl-framed windows represent $17 \%$ of windows used in new residential construction in 1993 and their share of the market doubled between 1991 to 1993 (AAMA 1994). Thus, the acceptance and growth of vinyl-framed windows in new construction is well under way and is expected to continue.

Many types of windows were ultimately not included in this economic analysis (see Table 5) because they were not prevalent in the market or were not the most cost effective from a strict energy standpoint. For example, triple-pane windows are available from some manufacturers, but were not included in this analysis because of the small number of manufacturers offering such a window, lack of cost data, and less-expensive options for obtaining equivalent efficiency. It is worth noting that the thermal 
efficiency of high-performance, double-paned windows included in this analysis equals the thermal efficiency of normal triple-paned glass. Woodframed windows can be highly energy efficient but are more expensive than equally energy-efficient vinyl-framed windows.

The window costs in both the Washington and California data were the total costs of windows as sold by the manufacturer to mid-sized builders. Installation costs and contractor profit had to be added to these costs. No installation cost increases for vinyl, argon, or low-E windows were applied. Means (1994) listed a window-installation subcontractor overhead and profit margin of $26 \%$ for a standard double-paned window. This was applied to all the window EEMs. A $10 \%$ profit for the general contractor (Means 1994) was applied on top of all other costs.

Window $\mathrm{U}_{\mathrm{o}}$-values had to be established for the types of windows examined here. The window types used in this analysis are shown in Table 8. The $\mathrm{U}_{0}$-values are based on median values of windows given in the National Fenestration Rating Council Certified Products Directory (NFRC 1994). For each of the four window types included in this analysis, there are at least 98 National Fenestration Rating Council-certified products available. $\mathrm{U}_{\mathrm{o}}$-values for available windows vary considerably about these median values. Window costs were assumed to scale linearly, with $U_{0}$-value between the values shown in Table 8. For compliance with the 1993 MEC in Springfield, windows with a $\mathrm{U}_{\mathrm{o}}$-value of 0.63 were required, which could either be highly efficient double-paned aluminum-framed windows or inefficient double-paned vinyl-framed windows. For Steamboat Springs, windows with a $\mathrm{U}_{0}$-value of 0.33 were required; therefore, a slightly better than median double-paned vinyl-framed window with argon and low-E was assumed with a higher cost extrapolated.

Table 8. Window $\mathrm{U}_{0}-$ Values and Costs

\begin{tabular}{|l|c|c|}
\hline \multicolumn{1}{|c|}{ Window/Frame Type } & $\begin{array}{c}\text { Window } \\
\mathrm{U}_{\mathrm{o}} \text {-Value }\end{array}$ & $\begin{array}{c}\text { Cost Relative to Double- } \\
\text { Paned Aluminum-Framed } \\
\left(\$ / \mathrm{ft}^{2}\right)\end{array}$ \\
\hline \hline Double aluminum & 0.72 & 0 \\
Double vinyl & 0.50 & 2.70 \\
Double vinyl, with low-E & 0.38 & 3.70 \\
Double vinyl, with argon, & 0.34 & 4.80 \\
low-E & & \\
\hline
\end{tabular}

Doors

Steel doors with U-values of 0.19 (ASHRAE 1989) were assumed for both the current practice house and the house complying with the 1993 MEC. Because no change in doors was assumed, the cost of the doors is not relevant in this analysis. 
Basement Walls

\section{Prototype Single-Family Home}

The foundation type assumed in this analysis was a full basement. Insulating the interior side of the basement wall was assumed to be the method of complying with the 1993 MEC. Vinyl-faced fiberglass insulation was assumed in this analysis because this is the common method of insulating basements in Colorado. R-11 insulation is required for compliance with the 1993 MEC in all cities (see Table 5). The costs of this insulation were not available from any published cost data source, so a cost provided by Mr. Randy LaFon, Sutton Insulation, Lakewood, Colorado, was used. The installed price of R-11 was quoted to be $\$ 0.50 / \mathrm{ft}^{2}$; this was scaled up by $30 \%$ to $\$ 0.65 / \mathrm{ft}^{2}$ to account for builder profit and overhead. Compliance with the $1993 \mathrm{MEC}$ can also be achieved by insulating the exterior of the s basement wall with rigid foam insulation or, if the basement is unheated, insulating the basement ceiling to R-19.

The median floor area for a new single-family home (DOC 1992) was $1890 \mathrm{ft}^{2}$. A survey of new single-family homes (NAHB 1991b) indicates two-story homes are most common in Colorado, with split-level and onestory homes not uncommon. From an energy point of view, a split-level design is similar to a two-story design; therefore a split-level home, with a floor area of $1890 \mathrm{ft}^{2}$, was assumed in this analysis: 8-ft-high ceilings; ceiling area (bordering the unconditioned attic) of $1418 \mathrm{ft}^{2}$; gross exterior above-grade wall area of $1736 \mathrm{ft}^{2}$; and basement wall area of $1240 \mathrm{ft}^{2}$. A total door area of $56 \mathrm{ft}^{2}$ (approximately 3 doors) was used (Johnson 1987).

As described above, a fully conditioned basement was assumed. Many new houses in Colorado have at least a partial crawl space that is often vented and have wall insulation. Crawl spaces were not considered here because the ARES software cannot adequately model crawl spaces with stem-wall insulation. The effectiveness of the crawl-space-wall insulation is greatly diminished by the vents, which allow outside air to enter the crawl space and bypass the insulation. However, compliance with the 1993 MEC is achieved if crawl-space walls are insulated to R-19. Compliance is also achieved by insulating any floor over an unheated space to R-19.

Windows have much higher $\mathrm{U}_{0}$-values than opaque walls. Therefore, the amount of window area has a major effect on the gross wall $\mathrm{U}_{\mathrm{o}}$-value, and, therefore, affects compliance with the 1993 MEC. Homes with high window areas will need greater levels of energy efficiency to comply with the 1993 MEC. Obtaining data on window area in new single-family housing proved difficult. An older source (NAHB 1981) reported a national average of $10.3 \%$ in 1980 . One source (Johnson 1987) indicated a national average window area of approximately $12 \%$ of the floor area. The most current published source identified (Mundy 1991) reported an estimated average of $410 \mathrm{ft}^{2}$ of flat glass sold per new house. Note that this is the area for the glass, not the window; double-pane glazing requires twice the glass needed for single glazing. In a personal communication, Mr. Eric J. Mundy, The Freedonia Group, Inc., Cleveland, Ohio, updated this value for 1992 . He estimated that the average for 1992 was $430 \mathrm{ft}^{2}$ per residence. Accounting for double-paned windows, storm windows, and storm doors, an average of 
approximately $220 \mathrm{ft}^{2}$ of window area in new houses was estimated (AAMA 1992). This corresponds to a window area of approximately $11 \%$ to $12 \%$ of the floor area for the prototype (or a wall with $12 \%$ to $13 \%$ glazing). A second method was used to try to estimate the window area in new homes. Mundy (1991) reported 595 million $\mathrm{ft}^{2}$ of glass sold in 1990 in the new residential market. Using data on new housing construction (DOC 1992), the average window-to-floor area (across all types of residential housing units) was estimated to be approximately $13 \%$ to $14 \%$.

All of the sources for single-family window areas indicate a window-tofloor area ratio of $14 \%$ or less; however, this is an average value. The distribution of window areas in new housing varies around this average. For this analysis, a window area of $14 \%$ of the wall area $\left(243 \mathrm{ft}^{2}\right.$, or $12.8 \%$ of the conditioned floor area) was assumed.

Heating, Ventilating, and Air-Conditioning Specifications
The heating-fuel types and equipment assumed in this analysis are shown in Table 9. The results given in the cost-effectiveness section were averaged across heating-fuel/equipment types, using shares based on a state-by-state survey of new houses (NAHB 1991b). The results are weighted heavily toward natural gas heating, which is by far the most common type of heating-fuel source used in new Colorado homes. Central air conditioning was assumed in Springfield and Denver only. An air-ducted distribution system was assumed for all cities.

Table 9. Equipment Shares and Efficiencies

\begin{tabular}{|c|c|c|}
\hline System & Share & Efficiency \\
\hline Natural gas furnace & $89 \%$ & $\begin{array}{l}0.78 \text { annual fuel } \\
\text { utilization efficiency }\end{array}$ \\
\hline Electric baseboard & $6 \%$ & $100 \%$ \\
\hline Electric heat pump & $5 \%$ & $\begin{array}{l}6.8 \text { heating seasonal } \\
\text { performance factor }\end{array}$ \\
\hline Air conditioner ${ }^{(a)}$ & $\begin{array}{l}\text { Springfield } \\
\text { and Denver }\end{array}$ & $\begin{array}{l}10.0 \text { seasonal energy } \\
\text { efficiency ratio }\end{array}$ \\
\hline
\end{tabular}

The minimum efficiency of residential heating, ventilating, and airconditioning equipment and water-heating equipment are set by mandatory national requirements in the National Appliance Energy Conservation Act of 1987. The heating- and cooling-equipment efficiencies in this analysis were set at the minimum levels allowed by the act as shown in Table 9 .

The effect of heating- and cooling-equipment downsizing is included in this analysis automatically by the ARES software (DOE 1989b). Smaller 
heating or cooling loads reduce required equipment capacities, and the equipment cost declines accordingly. This equipment cost change is small.

Distribution Systems Efficiency
A single distribution-efficiency factor for air-duct systems was used in this analysis. Recent research and field measurements have shown duct losses to be a major inefficiency. This value was determined by reviewing relevant work from recognized experts in the building science technical community and then contacting the respective authors and discussing their findings in light of the objective. These sources (given in Conner and Lucas 1994) were in reasonable agreement, and average values of $75 \%$ duct efficiency (i.e., $25 \%$ loss) were used in this analysis. 


\section{References}

American Architectural Manufacturers Association (AAMA). 1992. Study of the Residential Window and Skylight Markets. Palatine, Illinois.

American Architectural Manufacturers Association (AAMA). 1994. Industrial Statistical Review and Forecast: 1993. Palatine, Illinois.

American Society of Heating, Refrigerating and Air-Conditioning Engineers, Inc. (ASHRAE). 1989. ASHRAE Handbook, 1989 Fundamentals Volume. Atlanta, Georgia.

Barnett, C., and P. Thor. 1990. Construction Cost Analysis for the Residential Construction Demonstration Project - Cycle II. Bonneville Power Administration, Portland, Oregon.

Byers, D. 1990. The Cost of Energy Efficient Windows in Washington. WAOENG \#89-61, Washington State Energy Office, Olympia, Washington.

Congressional Record - House (CRH), "House Conference Report No. 102-1018," October 5, 1992, H2472.

Conner, C. C., and R. G. Lucas. 1994. Technical Support Document for Proposed 1994 Revision of the Model Energy Code Thermal Envelope Requirements. PNL-9400, Pacific Northwest Laboratory, Richland, Washington.

Consumers' Research. September 1991. "The Effect of Higher Prices On Housing Affordability." p. 12.

Council of American Building Officials (CABO). 1993. Model Energy Code, 1993 Edition. Falls Church, Virginia.

Craftsman Book Company (Craftsman). 1992. 1992 National Construction Estimator. Carlsbad, California.

Eley Associates (Eley). 1991. Volume 1: Low-Rise Residential Confidence and Sensitivity Study, Life-Cycle Cost Analysis. San Francisco, California.

Energy Information Administration (EIA). 1993. Annual Energy Outlook. DOE/EIA-0383(93), U.S. Department of Energy, Washington, D.C.

Energy Information Administration (EIA). 1995. Monthly Energy Review. DOE/EIA-0035(95/03), U.S. Department of Energy, Washington, D.C. 
Fryer, L., and N. Schalch. 1992. "Development and Implementation of a Multi-Utility Residential New Construction Program: The Energy Crafted Home Program." In Volume 5 - Utility Programs - Proceedings of the ACEEE 1992 Summer Study on Energy Efficiency in Buildings, pp. 63-73. American Council for an Energy-Efficient Economy, Washington, D.C.

Gerhardinger, P. F., and A. M. Flagg. 1992. "Energy Conservation in Existing Buildings Using High Performance Pyrolytic Low-E Glass." In Volume 1 - Commercial Technologies: Design and Operation - Proceedings of the ACEEE 1992 Summer Study on Energy Efficiency in Buildings, pp. 81-87. American Council for an Energy-Efficient Economy, Washington, D.C.

Internal Revenue Service. 1992. Statistics of Income 1989, Individual Income Tax Returns. Washington, D.C.

Johnson, A. W. 1987. A Preliminary Analysis of Proposal 87-20 (MMA) to the Model Energy Code. Johnson and Associates, Gaithersburg, Maryland.

Lortz, V. B., and Z. T. Taylor. 1989. Recommendations for Energy Conservation Standards for New Residential Buildings. Volume 2: Automated Residential Energy Standard-User's Guide - Version 1.1. PNL-6878 Vol. 2, Pacific Northwest Laboratory, Richland, Washington.

R. S. Means Company, Inc. (Means). 1992. Means Residential Cost Data--1993. Kingston, Massachusetts.

R. S. Means Company, Inc. (Means). 1994. Means Residential Cost Data--1995. Kingston, Massachusetts.

Money. January 1992. "From Tax Heaven in Alaska to Hell in New York." pp. 74-75.

Mundy, E. 1991. Flat Glass Products and Markets. Business Research Report B269, The Freedonia Group, Inc., Cleveland Ohio.

National Appliance Energy Conservation Act of 1987, Public Law 100-12, 42 USC 6291 et seq., as amended.

National Association of Home Builders (NAHB). 1981. 1980 Base Case and Feasibility Analysis. NAHB Research Center, Upper Marlboro, Maryland.

National Association of Home Builders (NAHB). 1986. An Economic Data Base in Support of SPC 90.2: Costs of Residential Energy, Thermal Envelope and HVAC Equipment. NAHB Research Center, Upper Marlboro, Maryland. 
National Association of Home Builders (NAHB). 1988. Wood Frame House Construction. Home Builder Press, Washington, D.C.

National Association of Home Builders (NAHB). 1991a. Builder Magazine. March 1991, p. 146.

National Association of Home Builders (NAHB). 1991b. 1991 NAHB Research Foundation Special Report. NAHB Research Center, Upper Marlboro, Maryland.

National Association of Home Builders (NAHB). 1992a. Resolution 8, Cost Effective and Affordable Energy Codes, January 23, 1992. NAHB Research Center, Upper Marlboro, Maryland.

National Association of Home Builders (NAHB). 1992b. Profile of the New Home Buyer. Washington, D.C.

National Association of Realtors (NAR). 1992. The Homebuying and Selling Process: 1991. Chicago, Illinois.

National Fenestration Rating Council (NFRC). 1994. Certified Products Directory. Second Edition. Silver Spring, Maryland.

National Institute of Standards and Technology (NIST). 1994. Energy Price Indices and Discount Factors for Life-Cycle Cost Analysis 1995. NISTIR 85-3273-9 (Rev. 10/94), U.S. Department of Commerce, Gaithersburg, Maryland.

Pacific Northwest Laboratory. 1994. $M E C_{C H E C S^{\text {Th }}}$ Version 1.0--Software User's Guide. PNL-10181. Pacific Northwest Laboratory, Richland, Washington.

U.S. Department of Commerce (DOC). 1991a. Statistical Abstract of the United States. Bureau of the Census, U.S. Government Printing Office, Washington, D.C.

U.S. Department of Commerce (DOC). 1991b. American Housing Survey for the United States in 1989. H150/89, Bureau of the Census, U.S. Government Printing Office, Washington, D.C.

U.S. Department of Commerce (DOC). 1992. Characteristics of New Housing: 1991. C25-91-A, Washington, D.C.

U.S. Department of Commerce (DOC). 1994. Survey of Current Business. Bureau of Economic Analysis, Washington, D.C.

U.S. Department of Energy (DOE). 1988. Technical Support Document in Support of Proposed Interim Energy Conservation Standards for New Federal Residential Buildings. DOE/CE-0223, Vol. 2, Washington, D.C. 
U.S. Department of Energy (DOE). 1989a. Technical Support Documentation for the Automated Residential Energy Standards (ARES) - In Support of Proposed Interim Energy Conservation Voluntary Performance Standards for New Non-Federal Residential Buildings. DOE/CE-0274, Vol. 4, Washington, D.C.

U.S. Department of Energy (DOE). 1989b. Technical Support Documentation for the Automated Residential Energy Standards (ARES) - In Support of Proposed Interim Energy Conservation Voluntary Performance Standards for New Non-Federal Residential Buildings. DOE/CE-0274, Vol. 2, Washington, D.C.

U.S. Office of Thrift Supervision (OTS). 1991. Rates and Terms on Conventional Home Mortgages. Federal Housing Finance Board, Washington, D.C. 


\section{Appendix}

Selection of Alternate Investment Rate 


\section{Selection of Alternate Investment Rate}

An analysis of energy-efficiency measures must convert costs and benefits occurring in future years into present-value dollars. To convert future dollars into present dollars, an alternate investment rate or discount rate needs to be established. Six possible discount rates are discussed here: two types of rates pertain to a social perspective and four different private rates pertain to an individual's perspective. The six rates are the following:

- the risk-free social rate

- the social rate for the analysis of government programs

- the implicit private discount rate

- the private rate charged for credit for consumer purchases

- the private market rate for personal monetary investment

- the private mortgage loan rate.

To justify using one of the social discount rates, it could be argued that the objective of setting energy-efficiency requirements in codes and standards is to reduce energy consumption for a state or the nation as a whole. One social rate is the risk-free rate, which is usually specified as the cost of government borrowing (i.e., an ostensibly risk-free market). In this case, the rate on long-term government bonds is one possible rate. In recent years, the long-term government bond rate has varied from $2.8 \%$ real (National Institute of Standards and Technology [NIST] 1994) to $4.7 \%$ real (NIST 1990).

Another social rate is used for analyzing energy-efficiency investments made by government programs and projects. For federal projects, the government will use the Federal Energy Management Program rate of 3.0\% in 1995; this is based on the real return on 30-year treasury bonds (NIST 1994). This is the rate that federal projects would be required to use for energy-efficiency projects undertaken with federal funds.

An "individual" discount rate is an implicit discount rate identified by observing consumer behavior. This rate represents the private rate of return that an individual consumer requires from a purchase. The strongest argument for this rate is that the purpose of the energy codes and standards is to properly reflect the interests of the consumer in housing "services" and, therefore, the consumer's preferences most appropriately reflect those interests.

The consumer's implicit discount rate (time value of money) is sometimes determined by examining consumer behavior when given a range of options. For instance, consumers can purchase a wide range of air conditioners at various efficiencies. Data on the mix of air-conditioner efficiencies actually purchased and the purchase prices can be used to define the price the consumer appears to be willing to pay for energy dollar savings resulting from increases in air-conditioner efficiency. In practice, discount rates are difficult to determine, with an extremely wide range of rates 
having been reported. The rates vary greatly across individuals and income levels. Uncertainties, such as whether the consumer has sufficient information to compare options, complicate determining the rate. According to the Electric Power Research Institute, discount rates varying from less than $2 \%$ to well over $100 \%$ have been reported for purchases related to energy efficiency (EPRI 1988, p. 2-22). Studies of the implicit discount rates generally would suggest higher discount rates than those found in the monetary investments described below. Because of the wide variation in reported rates and uncertainty about the consumer's ability to evaluate the options, the consumer's private rate of time preference, as demonstrated by the evidence of consumer purchases, was considered too indeterminate to use in this analysis.

Another possible rate is the rate charged for other consumer credit, such as credit card purchases. The interest rate charged for credit card purchases usually ranges from greater than $10 \%$ to approximately $20 \%$. The argument for the appropriateness of that rate is based on the fact that many consumer durables, such as washers, dryers, and dishwashers, are purchased through the use of a credit card and paid for over time. An argument against the use of that rate is that, in this analysis, the consumer is actually purchasing additional energy-efficiency measures in a home, not a new appliance; therefore, the consumer has access to a different credit market than that typically used to purchase a new appliance.

When considering how appropriate credit card interest rates are as a discount rate, the effective interest rate actually paid by consumers and the nonmonetary benefits of credit card use need to be considered. Many consumers pay off credit card bills before they are charged interest, indicating that their discount rate is below that charged by the credit card company. Additionally, many credit cards have a "grace period" between the consumer purchase and the initiation of the interest charges, lowering the effective interest rate charged. Finally, nonmonetary drivers, such as the need to track expenses, sometimes provide a reason for using credit cards.

One alternative for establishing a discount rate is to select the most common interest-bearing investment made by home buyers. Passbook savings accounts are probably the most common form of interest-bearing investments for homeowners. An argument can be made that consumers putting their money in a passbook savings account indicates that their discount rate is at or below their passbook savings rates. However, the real rate of return (savings interest rate less inflation) often is near $0 \%$, which is equivalent to the assumption that the value of money received in the future is almost the same as money received in the present. For that reason, the passbook savings rate is clearly too low for this analysis.

Another possible rate is the market rate for monetary investments. Consumers have access to a number of common market rates. These alternative investments can be used for comparison to investments in energy-efficiency measures. Using the consumer's alternative monetary investments for comparison, "The discount rate should reflect the rate of return that will be 
foregone if the project in question is undertaken instead of the next best alternative investment opportunity of similar risk; that is, it should reflect the 'opportunity cost' of the project" (Ruegg and Petersen 1987, p. 17). This criterion requires selecting the consumer's best available rate of return with comparable risk and liquidity. Passbook savings accounts generally pay low rates. U.S. Savings Bonds and short- and medium-term certificates of deposit interest rates are usually higher. These investments are relatively risk free and have a moderate to high degree of liquidity.

Another alternative "investment" for the consumer, which is comparable to the market rates for investment, is prepayment of the mortgage. In determining the rate of return from the prepayment alternative, the loss of the tax deduction for mortgage interest (if any) and loan prepayment penalty (if any) need to be considered. (Savings from energy efficiency are tax free to the homeowner.) Assuming no loan prepayment penalty and deduction of the mortgage interest, the net rate available to the homeowner who deducted the interest from his taxes for an "investment" in mortgage prepayment would be approximately $5.5 \%,{ }^{(a)}$ or $1.5 \%$ real accounting for the projected $3.9 \%$ inflation. Therefore, the prepayment "investment" yields between $5.5 \%$ and $8.0 \%$ nominal (i.e., not adjusted for inflation) or between $1.5 \%$ and $4.0 \%$ real, with the average value being at the low end because most homeowners take the mortgage tax deduction. This option is risk free. In contrast to most of the other investments, prepaying the mortgage would cost the consumer liquidity. An argument for using the mortgage interest rate (at a minimum) is that the home buyer has borrowed money at that rate, demonstrating that his implicit discount rate must be at least that high.

Using the criterion that the standard must be developed based on costs to the owner using the next best alternative investment opportunity, the best rate of return commonly available to the owner of the home is mortgage prepayment, yielding a real return of approximately $1.5 \%$ to $4.0 \%$. This range was selected as the possible range for the discount rate for this analysis. Because the long-term treasury bond rates for recent years is within this range, this real discount rate of $4.0 \%$ (8.1\% nominal, if a $3.9 \%$ inflation rate is included) was used in this analysis. This rate is probably above the average rate established by prepayment of the mortgage.

\section{References}

Electric Power Research Institute (EPRI). 1988. Implicit Discount Rates in Residential Customer Choices: Volume 1: Investments in Energy Conservation Measures. EPRI EM-5587, Palo Alto, California.

(a) The maximum federal income tax rate is assumed to be $28 \%$. The average marginal state income tax is estimated to be $3 \%$. The $8.0 \%$ return less the tax deductions of $31 \%$ ( $28 \%$ federal plus $3 \%$ state), yields a $5.5 \%$ nominal return. 
National Institute of Standards and Technology (NIST). 1990. Energy Prices and Discount Factors for Life-Cycle Cost Analysis 1991. NISTIR 85-3273-5, Gaithersburg, Maryland.

National Institute of Standards and Technology (NIST). 1994. Energy Prices and Discount Factors for Life-Cycle. Cost Analysis 1995. NISTIR 85-3273-9, Gaithersburg, Maryland.

Ruegg, R. T., and S. R. Petersen. 1987. Comprehensive Guide for Least Cost Energy Decisions. NBS Special Publication 709, National Bureau of Standards, Gaithersburg, Maryland. 


\section{Distribution}

No. of

Copies

OFFSITE

2 DOE/Office of Scientific and Technical Information

3 U.S. Department of Energy Office of Codes and Standards 1000 Independence Ave. SW

Washington, DC 20585

Attn:J. J. Boulen, EE-43

S. J. Turchen, EE-43

S. P. Walder, EE-43

20 R. Cowlishaw

Colorado Office of Energy Conservation 1675 Broadway, Suite 1300

Denver, CO 80202-4613
No. of

Copies

ONSITE

DOE Richland Operations Office

J. K. Schmitz

K8-50

18 Pacific Northwest Laboratory

J. L. Carlson, Program Files (5)

K5-02

C. C. Conner

R. G. Lucas (5)

K5-16

K5-16

B. V. Johnston

K9-41

Publishing Coordination

Technical Report Files (5) 